\author{
Giovanni Mazzotta \\ Francesca Floridi \\ Andrea Alberti \\ Paola Sarchielli
}

\section{Antiepileptic drugs in migraine prophylaxis}

\author{
G. Mazzotta (西) • F. Floridi • A. Alberti \\ P. Sarchielli \\ Department of Neuroscience, \\ University of Perugia, \\ Via E. Dal Pozzo, \\ I-06126 Perugia, Italy \\ e-mail: mazzotta@unipg.it \\ Tel.: +39-075-5783562 \\ Fax: +39-075-5783583
}

\begin{abstract}
Research in the field of headache treatment has experienced a marked impetus in the last few years. In the era of the triptans, the treatment modality of this disease has been revolutionised, and though most of the studies conducted have investigated the symptomatic treatment of migraine, less attention has been dedicated to migraine prophylaxis. This review considers the current data available in the literature regarding the use of antiepilep-
\end{abstract}

tic drugs in migraine prophylaxis, noting the clinical studies that have yielded statistically significant data.

Key words Migraine prophylaxis • Antiepileptics

\section{Introduction}

The decision to begin prophylactic therapy for the treatment of migraine depends on the frequency and the severity of the attacks, and to what extent they alter the quality of life of the patients. According to the Diagnostic and Therapeutic Guidelines for migraine and cluster headache of the Italian Society for the Study of Headaches [1], the presence of at least 2 attacks of migraine per month or lasting 4 or more days per month, which do not completely respond to symptomatic therapy, are indications to begin prophylactic therapy.

A state of hyperexcitability of the cerebral cortex is considered the neuropathophysiologic basis of migraine, as in epilepsy, and in fact the two pathologies are often comorbid [2]. In a population study, Ottman and Lipton [3] demonstrated that epilepsy and migraine are closely linked pathologic conditions, independent of seizure aetiology, age at first onset and type of crisis. These features, which are shared by these pathologies characterised by attacks, suggest a common pathogenesis involving membrane excitability upon which the antiepileptic drugs can act.

From this point of view, the studies of efficacy and tolerability confirm and delineate antiepileptics as very promising drugs in the panorama of the prevention of migraine and other head pain.

Antiepileptic and antimigraine drugs act on the nociceptive mechanisms mediated by GABA or glutamate neurotransmission, or both [4]. GABA is the major inhibitory neurotransmitter in the central nervous system and its presynaptic release occurs by a calcium-dependent mechanism [5]. Valproate and gabapentin interfere with GABA metabolism, inhibiting its degradation and transformation into succinate [6], and topiramate potentiates GABA-mediated inhibition by facilitating receptor action [7]. GABA binding to its receptors causes cellular hyperpolarisation and inhibition of postsynaptic transmission. All these drugs modulate the activity of calcium, sodium and potassium ion channels by hyperpolarising and stabilising the membrane [4]. 


\section{Sodium valproate}

Sodium valproate, more frequently marketed as its stable coordination product, divalproate (divalproex sodium), is the only antiepileptic drug in the United States approved by the Food and Drug Administration for migraine prophylaxis, as has been demonstrated with excellent results in randomised clinical studies [5, 8-14]. In a more recent study conducted by Freitag et al. [8], a reduction in the weekly frequency of headache was significantly greater in the study group than in the placebo group $(p=0.006)$. The antiepileptic and antimigraine properties of sodium valproate are due to its effects on GABA-mediated neurotransmission, blockade of sodium and calcium ion channels, and modulation of the release of excitatory amino acids [15]. The strong membrane stabilising effect makes valproate the prophylactic drug of first choice in the case of headache with mood disturbance or epilepsy. The main side effects are somnolence, nausea and other gastrointestinal disturbances, alopecia, tremor and weight gain [15]. It may have possible teratogenic effects on neural tube development and thus it should not be used in case of pregnancy [15]. Chronic use at elevated dosages may cause hepatic toxicity [15], and so it should be used with caution in subjects who are taking antiaggregants or anticoagulants because the association with valproate can interfere with haemostasis and coagulation [15]. It was shown that $21 \%$ of patients in preventive therapy with valproate stopped treatment due to undesirable effects, and this has lead to a debate on the utility of identifying, even using serum dosages of the drug, a minimum effective dose that does not cause serious undesirable effects [16]. Recently, studies on valproate have evaluated the intravenous administration of the drug, which seems to offer better results for chronic headache and for acute phase therapy [17].

Among the new generation of antiepileptic drugs, many studies have investigated topiramate, gabapentin, lamotrigine and levetiracetam.

\section{Topiramate}

Topiramate, introduced for the first time in 1995 in AngloSaxon countries for the therapy of partial seizures, produces a membrane-stabilising effect by blocking sodium, calcium and potassium ion channels, and by modulating GABA and glutamate-mediated activity. Many recent studies, even those conducted in children [18], have shown efficacy in migraine prophylaxis, both for migraine without aura and presently also for that with aura [19], and also in other forms of primary headache, yielding good results both in terms of frequency and efficacy at dosages of $100 \mathrm{mg} /$ day [18, 20-29]. In a study just published, Brandes et al. [23] demonstrated that the average monthly headache crisis frequency was reduced signifi- cantly, even at the dosage of $100 \mathrm{mg} /$ day of topiramate $(p=0.008)$ as well as at that of $200 \mathrm{mg} /$ day $(p<0.001)$ compared to placebo. The most frequent side effects [30] of weight loss, paraesthesiae and dysgeusias were rarely caused by the discontinuation of therapy. These results make topiramate a very interesting molecule for migraine prophylaxis.

\section{Gabapentin}

Gabapentin interferes with the metabolism of GABA into its metabolite, succinate, and can modulate, as the other antiepileptic drugs, GABA-mediated neurotransmission [31]. It may also be involved in the inhibition of sodium and calcium ion channels [31]. Gabapentin is currently used in the treatment of chronic pain syndromes, such as SUNCT, trigeminal neuralgia or cluster headache [32]. The study of gabapentin in migraine, with recent randomised, open studies [33] and double-blind studies with placebo [34, 35], are yielding positive results. In the study of Jimenez-Hernandez et al. [33], a statistically significant difference was found between the treatment with gabapentin and the baseline condition of the patients, both for the reduction in the number of attacks and for the reduction in intensity and increase in the pain-free intervals. The most frequent side effects were somnolence and vertigo, symptoms well tolerated by the patients [31].

\section{Lamotrigine}

Lamotrigine is an antagonist of glutamate-mediated activity due to its blockade of voltage-dependent sodium ion channels [31]. It is a well-tolerated drug and the most undesirable effect is skin rash [31]. Studies on the use of lamotrigine for headache have yielded contrasting results; in one study it furnished significant data only for migraine with aura [36-38].

\section{Levetiracetam}

Levetiracetam, a new antiepileptic drug used as adjunctive therapy in the treatment of partial crises with or without generalisation, has a mechanism of action which is mostly unknown [31]. It acts selectively on autonomous neuronal activity, without any effect on normal neuronal characteristics. Specific receptor binding has not been shown, although recently the ability to selectively inhibit some voltage-dependent ion channels has been demonstrated [39]. The drug is well tolerated and the undesirable effects, though rare, are: somnolence, asthenia and postural instability [31]. For migraine therapy, few studies 
are available in the literature regarding the use of levetiracetam for both the prophylaxis and attack of migraine. These studies have yielded encouraging results [40-43], even in children, with a recent retrospective study [44].

\section{Conclusions}

In the last few years, the use of antiepileptic drugs in migraine prophylaxis has become ever more widespread.
The efficacy of many of these drugs has been confirmed by diverse placebo-controlled studies.

The mechanism that underlies the efficacy of antiepileptic drugs in migraine prophylaxis seems to be related to its ability to modulate GABA or glutamatemediated neurotransmission, or both, in the disequilibrium between neuronal inhibition and excitation, which has been hypothesised for migraine. The data presented here are very encouraging for the clinician, who thus possesses a valid alternative for consideration in the prophylactic therapy of migraine.

\section{References}

1. Società Italiana per lo Studio delle Cefalee (2002) Linee Guida Diagnostiche e Terapeutiche dell'emicrania e della cefalea a grappolo. In: Gallai V, Pini LA (eds) Trattato delle Cefalee. Centro Scientifico Editore, Torino, pp L3-L141

2. Mazzotta G (2002) Ipereccitabilità neuromuscolare latente e test d'ischemia nei pazienti cefalalgici. In: Gallai V, Pini LA (eds) Trattato delle Cefalee. Centro Scientifico Editore, Torino, pp 143-151

3. Ottman R, Lipton RB (1994) Comorbidity of migraine and epilepsy. Neurology 44(11):2105-2110

4. Cutrer FM (2001) Antiepilectic drugs: how they work in headache. Headache 41[Suppl 1]:S3-S10

5. Ghose K, Niven B (1998) Prophylactic sodium valproate therapy in patients with drug-resistant migraine. Methods Find Exp Clin Pharmacol 20(4):353-359

6. McNamara JO (2001) Drugs effective in the therapy of the epilepsies. In: Hardman JG, Limbird LE, Goodman Gilman A (eds) The pharmacological basis of therapeutics. McGraw Hill, p 536

7. Storey JR, Calder CS, Hart DE, Potter DL (2001) Topiramate in migraine prevention: a double-blind placebo-controlled study. Headache 41(10):968-975
8. Freitag FG, Collins SD, Carlson HA, Goldstein J, Saper J, Silberstein S, Mathew N, Winner PK, Deaton R, Sommerville K, Depakote ER: Migraine Study Group (2002) A randomized trial of divalproex sodium extended-release tablets in migraine prophylaxis. Neurology 58(11):1652-1659

9. Mitsikostas DD, Polychronidis I (1997) Valproate versus flunarizine in migraine prophylaxis: a randomized, double-open, clinical trial. Funct Neurol 12(5):267-276

10. Kaniecki RG (1997) A comparison of divalproex with propranolol and placebo for prophylaxis of migraine without aura. Arch Neurol 54(9):1141-1145

11. Klapper J (1997) Divalproex sodium in migraine prophylaxis: a dose-controlled study. Cephalalgia 17(2):103-108. Erratum in Cephalalgia 17(7):798

12. Mathew NT, Saper JR, Silberstein SD, Rankin L, Markley HG, Solomon S, Rapoport AM, Silber CJ, Deaton RL (1995) Migraine prophylaxis with divalproex. Arch Neurol 52(3):281-286

13. Jensen R, Brinck T, Olesen J (1994) Sodium valproate has a prophylactic effect in migraine without aura: a triple-blind, placebo-controlled crossover study. Neurology 44(4):647-651

14. Hering R, Kuritzky A (1992) Sodium valproate in prophylactic treatment of migraine: a double-blind study versus placebo. Cephalalgia 12(2):81-84
15. McNamara JO (2001) Drugs effective in the therapy of the epilepsies. In: Hardman JG, Limbird LE, Goodman Gilman A (eds) The pharmacological basis of therapeutics. McGraw Hill, p 537

16. Cerbo R, Bruti G, Mostardini C, Di Stani F, D'Agostino V, Villani V, Lenzi GL (2003) Il valproato di sodio. XVII Congresso Nazionale della Società Italiana per lo Studio delle Cefalee, Tirrenia (PI), 11-13 maggio 2003. Abstract Book, p 36

17. Tanen DA, Miller S, French T, Riffenburgh RH (2003) Intravenous sodium valproate versus prochlorperazine for the emergency department treatment of acute migraine headaches: a prospective, randomized, doubleblind trial. Ann Emerg Med 41(6):847-853

18. Hershey AD, Powers SW, Vockell AL, LeCates S, Kabbouche M (2002) Effectiveness of topiramate in the prevention of childhood headaches. Headache 42(8):810-818

19. Lampl C, Bonelli S, Ransmayr G (2004) Efficacy of topiramate in migraine aura prophylaxis: preliminary results of 12 patients. Headache 44(2):174-176

20. Silvestrini M, Bartolini M, Coccia M, Baruffaldi R, Taffi R, Provinciali L (2003) Topiramate in the treatment of chronic migraine. Cephalalgia 23(8):820-824

21. Edwards KR, Potter DL, Wu SC, Kamin M, Hulihan J (2003) Topiramate in the preventive treatment of episodic migraine: a combined analysis from pilot, double-blind, placebo-controlled trials. CNS Spectr 8(6):428-432 
22. Storey JR, Calder CS, Hart DE, Potter DL (2001) Topiramate in migraine prevention: a double-blind, placebo-controlled study. Headache 41(10):968-975

23. Brandes JL, Saper JR, Diamond M, Couch JR, Lewis DW, Schmitt J, Neto W, Schwabe S, Jacobs D: MIGR - 002 Study Group (2004) Topiramate for migraine prevention: a randomized controlled trial. JAMA 291(8):965-973

24. Martinez HR, Londono O, CantuMartinez L, del Carmen Tarin L, Castillo CD (2003) Topiramate as an adjunctive treatment in migraine prophylaxis. Headache 43(10):1080-1084

25. Pascual J, Sanchez del Rio M, Mateos V, Lainez JM, Hernandez-Gallego J, Leira R, Jimenez MD (2003) Topiramate for patients with refractory migraine: an observational, multicenter study in Spain. Neurologia 18(7):364-367

26. Von Seggern RL, Mannix LK, Adelman JU (2002) Efficacy of topiramate in migraine prophylaxis: a retrospective chart analysis. Headache 42(8):804-809

27. Mathew NT, Kailasam J, Meadors L (2002) Prophylaxis of migraine, transformed migraine, and cluster headache with topiramate. Headache 42(8):796-803

28. Young WB, Hopkins MM, Shechter AL, Silberstein SD (2002) Topiramate: a case series study in migraine prophylaxis. Cephalalgia 22(8):659-663

29. Matharu MS, Boes CJ, Goadsby PJ
(2002) SUNCT syndrome: prolonged attacks, refractoriness and response to topiramate. Neurology 58(8): 1307

30. McNamara JO (2001) Drugs effective in the therapy of the epilepsies. In: Hardman JG, Limbird LE, Goodman Gilman A (eds) The pharmacological basis of therapeutics. McGraw Hill, p 524

31. McNamara JO (2001) Drugs effective in the therapy of the epilepsies. In: Hardman JG, Limbird LE, Goodman Gilman A (eds) The pharmacological basis of therapeutics. McGraw Hill, pp 539-541

32. Pini LA, Brovia D (2002) Focus on: gabapentin and headache. XVII Congresso Nazionale della Società Italiana per lo Studio delle Cefalee, Tirrenia (PI), 11-13 maggio 2003. Abstract Book, p 34

33. Jimenez-Hernandez MD, Torrecillas Narvaez MD, Friera Acebal G (2002) [Effectiveness and safety of gabapentin in the preventive treatment of migraine]. Rev Neurol 35(7):603-606 [article in Spanish]

34. Mathew NT, Rapoport A, Saper J, Magnus L, Klapper J, Ramadan N, Stacey B, Tepper S (2001) Efficacy of gabapentin in migraine prophylaxis. Headache 41(2):119-128

35. Di Trapani G, Mei D, Marra C, Mazza S, Capuano A (2000) Gabapentin in the prophylaxis of migraine: a doubleblind randomized placebo-controlled study. Clin Ter 151(3):145-148
36. Steiner TJ, Findley LJ, Yuen AW (1997) Lamotrigine versus placebo in the prophylaxis of migraine with and without aura. Cephalalgia 17(2):109-112

37. D'Andrea G, Granella F, Cadaldini M, Manzoni GC (1999) Effectiveness of lamotrigine in the prophylaxis of migraine with aura: an open pilot study. Cephalalgia 19(1):64-66

38. Lampl C, Buzath A, Klinger D, Neumann K (1999) Lamotrigine in the prophylactic treatment of migraine aura - a pilot study. Cephalalgia 19(1):58-63

39. Lukyanetz EA, Shkryl VM, Kostyuk PG (2002) Selective blockade of Ntype calcium channels by levetiracetam. Epilepsia 43(1):9-18

40. Krusz JC (2001) Levetiracetam as prophylaxis for resistant headaches. Cephalalgia 373:P2-I12 (Abstract)

41. Drake ME (2001) Levetiracetam for preventive treatment of migraine. Cephalalgia 373:P2-I13 (Abstract)

42. Krusz JC (2002) Levetiracetam, given intravenously, for acute intractable migraines. Eur J Neurol 9[Suppl 2]:154 ABS P2177 (Abstract)

43. Gallai V, Alberti A, Rossi C, Sarchielli P (2002) Il Levetiracetam nella profilassi dell'emicrania. XVII Congresso Nazionale della Società Italiana per lo Studio delle Cefalee, Tirrenia (PI), 11-13 Maggio 2003. Abstract Book, p 35

44. Miller GS (2004) Efficacy and safety of levetiracetam in pediatric migraine. Headache 44(3):238-243 